\title{
Antimicrobial susceptibility of Francisella noatunensis subsp. noatunensis strains isolated from Atlantic cod Gadus morhua in Norway
}

\author{
Cecilie H. Isachsen ${ }^{1}$, Øivind Vågnes ${ }^{2}$, Ragnhild Aa. Jakobsen ${ }^{3}$, Ole B. Samuelsen ${ }^{1, *}$ \\ ${ }^{1}$ Institute of Marine Research, PO Box 1870 Nordnes, 5817 Bergen, Norway \\ ${ }^{2}$ National Veterinary Institute, PO Box 1263 Sentrum, 5811 Bergen, Norway \\ ${ }^{3}$ Department of Biology, University of Bergen, PO Box 7800, 5020 Bergen, Norway
}

\begin{abstract}
A total of 30 isolates of Francisella noatunensis subsp. noatunensis isolated from Atlantic cod Gadus morhua L. were tested for susceptibility, in the form of minimal inhibitory concentration (MIC) values, against the following antibacterial agents: flumequine, oxolinic acid, ciprofloxacin, florfenicol, oxytetracycline, erythromycin, streptomycin sulphate, trimetoprim/ sulphadiazine and rifampin. All the isolates had a low susceptibility to oxytetracycline, trimetoprim/sulphadiazine (Tribrissen ${ }^{\circledR}$ ), erythromycin, ciprofloxacin and streptomycin with MIC values of 64,64 to $128,16,8$ and 32 to $128 \mu \mathrm{g} \mathrm{ml}^{-1}$, respectively. The strains were, on the other hand, susceptible to florfenicol, oxolinic acid, flumequine and rifampin with MIC values of $0.5,0.25,0.25$ and 0.25 to $1 \mu \mathrm{g} \mathrm{ml}^{-1}$, respectively.
\end{abstract}

KEY WORDS: Francisella noatunensis subsp. noatunensis $\cdot$ Susceptibility $\cdot$ Atlantic cod

\section{INTRODUCTION}

The bacterium Francisella noatunensis subsp. noatunensis is a facultative intracellular bacterium causing the systemic granulomatous inflammatory disease francisellosis in cod Gadus morhua L. Since 2004, francisellosis has been found to increase in prevalence and severity, and Francisella sp. has been diagnosed in clinically infected cod from numerous grow-out facilities spanning most of the Norwegian coastline from Rogaland to Nordland (Olsen et al. 2006, Ottem et al. 2008, Hjeltnes 2009). This disease is now regarded as a major problem in the cultivation of cod in Norway (Hjeltnes 2009). Internationally, various Francisella spp. are known to cause disease epidemics in farmed and wild fish from fresh, brackish and marine water (Mikalsen 2008, Birkbeck et al. 2011). Treatment of francisellosis in cod with antibacterial agents has not yet been described in the literature.
In order to obtain a successful treatment, a bacterium must be susceptible to the antibacterial agent in use and the concentration of the drug achieved in the infected organ or organs must be high enough over a long enough period to have an effect. Pharmacokinetic data are available for the antibacterial agents flumequine, oxolinic acid, florfenicol and Romet ${ }^{\circledR} 30$, and a combination of ormethoprim and sulphadimetoxine, in cod (Hansen \& Horsberg 2000, Samuelsen et al. 2003a,b, Samuelsen 2006a,b). Basic knowledge of susceptibility, presented in the form of minimum inhibitory concentration (MIC) values of Francisella noatunensis subsp. noatunensis against antibacterial agents is, however, presently not available. The antibacterial agents oxytetracycline, florfenicol, flumequine, oxolinic acid and Tribrissen, and a combination of trimethoprim and sulfadiazine in a ratio of 1:5 are at present, or have been, licensed and used in Norwegian fish farming, whereas ciprofloxacin is a bactericidal drug that was found to be 
markedly more active against oxolinic-acid-resistant isolates of Aeromonas salmonicida (Lewin \& Hastings 1990). F. noatunensis subsp. noatunensis is a slowgrowing bacterium, and rifampin, erythromycin and streptomycin sulphate are all antibacterial agents that are used in human medicine in the treatment of Mycobacterium tuberculosis, another slow-growing bacterium. Erythromycin is also occasionally used against bacterial kidney disease (BKD) in salmonids.

The aim of the present study was to test the susceptibility, in the form of MIC values, to a number of isolates of Francisella noatunensis subsp. noatunensis against the selected group of antibacterial agents.

\section{MATERIALS AND METHODS}

\section{Bacterial strains}

A total of 30 isolates of Francisella noatunensis subsp. noatunensis from Atlantic cod Gadus morhua L. were analysed. Of these, 28 isolates were provided by the Norwegian Veterinary Institute (Norway) and 2 isolates, GM2212/LMG 24256 (Nylund et al. 2006, Ottem et al. 2007) and EK-4b, were provided by the Institute of Marine Research (Norway). All isolates originate from farmed cod, except EK-4b, which was isolated from a wild cod. The strains were previously identified as F. noatunensis subsp. noatunensis using the methods described by Ottem et al. (2008).

\section{Chemicals}

Flumequine, oxolinic acid, oxytetracycline, florfenicol, Tribrissen (trimethoprim/sulfadiazine), erythromycin, ciprofloxacin, streptomycin sulphate and rifampin were all obtained from Norwegian Medical Depot (Bergen, Norway). Stock solutions of antibacterial agents were prepared at a concentration of $1.0 \mathrm{mg} \mathrm{ml}^{-1}$ in methanol (florfenicol, Tribrissen, rifampin), in water (oxytetracycline, erythromycin, streptomycin sulphate), $0.03 \mathrm{M} \mathrm{NaOH}$ (flumequine, oxolic acid) and $0.03 \mathrm{M} \mathrm{NaOH} /$ methanol (1:1) (ciprofloxacin).

\section{MIC determination}

In order to meet the demands of Francisella noatunensis subsp. noatunensis for specific growth factors, the method of choice in the present work was a modified agar dilution test for the determinations of
MIC values (Alderman \& Smith 2001). Briefly, F. noatunensis subsp. noatunensis isolates were grown on modified Mueller-Hinton agar (MMHA) supplemented with $3 \%$ foetal bovine serum (FBS) (PAA Laboratories), $0.8 \%$ glucose (Merck), $0.4 \%$ L-cystein (Sigma) and $4 \%$ Yeastolate Ultrafiltrate (Gibco) and containing 2-fold dilutions of the antibacterial agents tested. All supplements and antibacterial agents were aseptically treated and added when the temperature of the agar (after sterilization $121^{\circ} \mathrm{C}, 15 \mathrm{~min}$ ) had fallen to $50^{\circ} \mathrm{C}$ (Andrews 2001), except FBS, which was added at $60^{\circ} \mathrm{C}$. Finally, pH was adjusted to $7.3 \pm 0.1$. Agar plates were inoculated with standardized inoculums of the different $F$. noatunensis subsp. noatunensis isolates and incubated for $72 \mathrm{~h}$ at $22^{\circ} \mathrm{C}$. Three controls included the solvents methanol, $0.03 \mathrm{M}$ sodium hydroxide, or water in amounts corresponding to the highest quantity present in the agar dilution assay. Inoculated agar plates without antibiotics served as positive controls. The type strain LMG 24256 was included on all test plates as control of the culture medium, as none of the recommended control strains were suitable for the specific medium required by $F$. noatunensis subsp. noatunensis (Alderman \& Smith 2001, Colquhoun \& Duodu 2011). Tests were performed in triplicate, and the MIC values were defined as the lowest concentration exhibiting no visible bacterial growth.

\section{RESULTS}

The MIC values for the various antibacterial agents are shown in Table 1. No variations between parallels and between isolates were found for most of the antibacterial agents. All the isolates had a low susceptibility to oxytetracycline, Tribrissen, erythromycin, ciprofloxacin and streptomycin sulphate. The isolates were susceptible to florfenicol, oxolinic acid, flumequine and rifampin. The results show that the MICs for all antibacterial agents and strains fell within a narrow range, apart from streptomycin, which showed greater variation.

The MIC values for the type strain LMG 24256 were similar to the clinical strains for all antibacterial agents, with the exception of streptomycin, where the MIC value for LMG 24256 was higher (128 $\left.\mu \mathrm{g} \mathrm{ml}^{-1}\right)$.

\section{DISCUSSION}

In order to establish correct dosage regimes and thereby promote optimal use of a drug, data derived 
Table 1. Minimum inhibitory concentration (MIC) of antibacterial agents against Francisella noatunensis isolates and $F$. noatunensis reference strain (LMG 24256)

\begin{tabular}{|lcccc|}
\hline Antibacterial agents & $\begin{array}{c}\text { Test range } \\
\left(\mu \mathrm{g} \mathrm{ml}^{-1}\right)\end{array}$ & \multicolumn{3}{c|}{ MIC value $\left(\mu \mathrm{g} \mathrm{m} \mathrm{m}^{-1}\right)$} \\
& & $(\mathrm{n}=28)$ & & \\
\hline Florfenicol & $0.03-2$ & $0.5^{\mathrm{a}}$ & $0.5^{\mathrm{a}}$ & $0.5^{\mathrm{a}}$ \\
Oxytetracycline & $4-128$ & 64 & 64 & 64 \\
Erythromycin & $2-128$ & 16 & 16 & 16 \\
Trimethoprim/ & $4-128$ & $64-128^{\mathrm{a}}$ & $64^{\mathrm{a}}$ & $64-128^{\mathrm{a}}$ \\
$\quad$ Sulfadiazine & & & & \\
Flumequine & $0.03-4$ & 0.25 & 0.25 & 0.25 \\
Oxolinic acid & $0.015-16$ & 0.25 & 0.25 & 0.25 \\
Ciprofloxacin & $0.12-16$ & 8 & 8 & 8 \\
Streptomycin sulphate & $4-128$ & $>32$ & $32-64$ & $>128$ \\
Rifampicin & $0.25-128$ & $0.25-1^{\mathrm{a}}$ & $0.251^{\mathrm{a}}$ & $0.25-1^{\mathrm{a}}$ \\
aNo growth in solvent control plate & & & \\
\hline
\end{tabular}

tion, they found their isolates to be less susceptible to streptomycin, erythromycin and potentiated sulphonamides and susceptible to florfenicol and fluoroquinolones (enrofloxacin and ciprofloxacin). However, unlike our results, they found their isolates to be susceptible to oxytetracycline (MIC value of $0.25 \mu \mathrm{g} \mathrm{ml}^{-1}$ ) and ciprofloxacin (MIC value of $0.5 \mu \mathrm{g} \mathrm{ml}^{-1}$ ).

According to Shojaee AliAbadi \& Lees (2000), the length of the period for which the concentration in plasma exceeds the MIC value is an important determinant for the outcome of therapy for bacteriostatic drugs. For the predominantly concentrationdependant bactericidal drugs with

from pharmacokinetic investigations and the pathogens' susceptibility to the drug in use are essential. However, pharmacokinetic data in fish are known to vary, e.g. with dose, temperature, salinity, species and size.

In cod, pharmacokinetic data are available for the antibacterial agents flumequine, oxolinic acid, florfenicol and Romet ${ }^{30}$ and where the studies were performed at ambient temperature, salinity and size and applying doses and regimes as recommended by the producers (Hansen \& Horsberg 2000, Samuelsen et al. 2003a,b, Samuelsen 2006a,b). For the remaining drugs, pharmacokinetic data from other fish species were used, introducing more inaccuracy in the concluding arguments.

In this investigation the susceptibility of various Francisella noatunensis subsp. noatunensis strains to both bacteriostatic drugs (florfenicol, oxytetracycline, erythromycin, Tribrissen) and bactericidal drugs (flumequine, oxolinic acid, ciprofloxacin, streptomycin sulphate, rifampin) were studied (Table 1). Few studies have been conducted to evaluate the antibacterial susceptibility to Francisella sp. strains isolated from fish. Bohle et al. (2009) reported MIC values of $0.25 \mu \mathrm{g}$ $\mathrm{ml}^{-1}$ for flumequine and oxolinic acid and $1.0 \mu \mathrm{g} \mathrm{ml}^{-1}$ for florfenicol for $F$. philomiragia cultures isolated from infected Atlantic salmon Salmo salar. These values are similar to the values found in the present study (Table 1). However, Bohle et al. (2009) also reported a MIC value of $0.5 \mu \mathrm{g} \mathrm{ml}^{-1}$ for oxytetracycline, which is much lower than the value of $64 \mu \mathrm{g} \mathrm{ml}^{-1}$ found in our investigation (Table 1). In a recent study, Soto et al. (2012) present MIC values for 10 isolates of F. noatunensis subsp. orientalis against a large number of antibacterial agents. Similar to our investiga- significant post-antibiotic effect, which include the bactericidal drugs tested here, the outcome of therapy requires the attainment of high concentrations and is correlated to the $\mathrm{AUC}_{0-24} / \mathrm{MIC}$ ratio, whereas prevention of the development of resistance is correlated with the $C_{\max } / \mathrm{MIC}$ ratio (Shojaee AliAbadi \& Lees 2000). $\mathrm{AUC}_{0-24}$ is defined as the area under the concentration (time curve from 0 to $24 \mathrm{~h}$ following a single administration of a drug), whereas $C_{\max }$ refers to the peak plasma concentration of the drug. For the quinolones, rifampin and streptomycin a $C_{\max } / \mathrm{MIC}$ ratio of 8 should be obtained and an $\mathrm{AUC}_{0-24} / \mathrm{MIC}$ ratio of 100 and, in some cases, 250 is desirable (Shojaee AliAbadi \& Lees 2000).

The MIC value for both flumequine and oxolinic acid for all the Francisella noatunensis subsp. noatunensis strains tested in this investigation was $0.25 \mu \mathrm{g} \mathrm{ml}^{-1}$. A single oral administration of $25 \mathrm{mg}$ $\mathrm{kg}^{-1}$ of oxolinic acid to cod resulted in a plasma $C_{\max }$ value of $1.2 \mu \mathrm{g} \mathrm{ml}^{-1}$ and an $\mathrm{AUC}_{0-24}$ value of $140 \mathrm{~h} \mu \mathrm{g}$ $\mathrm{ml}^{-1}$ (Samuelsen et al. 2003a). From these data, an AUC $_{0-24}$ value of approximately $23 \mathrm{~h} \mu \mathrm{g} \mathrm{ml}^{-1}$ could be calculated giving an $\mathrm{AUC}_{0-24} / \mathrm{MIC}$ ratio of 92 and a $C_{\max } / \mathrm{MIC}$ ratio of 4.8 . These values are slightly lower than recommended, and an increase in the daily dosage should be considered when using oxolinic acid. For flumequine, following administration of 10, 15 and $25 \mathrm{mg} \mathrm{kg}^{-1}$ on Days 1, 2, 3, 5, 7 and $9, C_{\max }$ values of $1.3,2.7$ and $4.5 \mu \mathrm{g} \mathrm{ml}^{-1}$, respectively, could be determined (Vik-Mo et al. 2005). The 2 highest doses resulted in $C_{\max } / \mathrm{MIC}$ values of $>8$, while the $10 \mathrm{mg} \mathrm{kg}^{-1}$ dose failed (Vik-Mo et al. 2005). Unfortunately, no AUC values could be determined from their study. However, based on data presented by Hansen \& Horsberg (2000), following a single oral 
dose of $10 \mathrm{mg} \mathrm{kg}^{-1}$ of flumequine, an $\mathrm{AUC}_{0-24}$ of approximately 60 to $70 \mathrm{~h} \mathrm{gg} \mathrm{ml}^{-1}$ could be determined giving an $\mathrm{AUC}_{0-24} / \mathrm{MIC}$ ratio of 240 to 280, indicating efficacy.

No pharmacokinetic studies are presented for streptomycin sulphate, ciprofloxacin, or rifampin in fish. However, MIC values above $32 \mathrm{\mu g} \mathrm{ml}^{-1}$ for streptomycin sulphate and $8 \mu \mathrm{g} \mathrm{ml}^{-1}$ for ciprofloxacin show that the susceptibilities of the isolates towards these drugs are low, and it is not likely that adequate concentrations can be achieved in the fish unless the administered dose is very high. For rifampin the high susceptibility may indicate potential efficacy, but this is an important drug in human medicine, and it is therefore unlikely that it will be licensed for use in aquaculture in Norway.

For the bacteriostatic drugs (florfenicol, oxytetracycline, erythromycin, Tribrissen) and time-dependant bactericidal drugs, the time for which concentration exceeds the MIC value is an important determinant for the outcome of therapy. In periods when concentrations decrease below MIC, re-growth of microbes occurs.

The MIC value for florfenicol for all the Francisella noatunensis subsp. noatunensis strains tested in this investigation was $0.5 \mathrm{\mu g} \mathrm{ml}^{-1}$. Pharmacokinetic data following a single oral dose of $10 \mathrm{mg} \mathrm{kg}^{-1}$ show that florfenicol is well absorbed in cod with $C_{\max }$ values of $10.8 \mu \mathrm{g} \mathrm{ml}^{-1}$ in plasma, $13.0 \mu \mathrm{g} \mathrm{g}^{-1}$ in muscle and $12.1 \mathrm{\mu g} \mathrm{g} \mathrm{g}^{-1}$ in liver and is eliminated slowly with an elimination half-life $\left(t_{1 / 2} \beta\right)$ value of $39 \mathrm{~h}$ in plasma, $21 \mathrm{~h}$ in muscle and $23 \mathrm{~h}$ in liver (Samuelsen et al. 2003b). Following $10 \mathrm{~d}$ of medication with 10 and $20 \mathrm{mg}$ florfenicol $\mathrm{kg}^{-1}$ fish $\mathrm{d}^{-1}$, produced plasma and muscle concentrations of $5.0 \mu \mathrm{g} \mathrm{ml}^{-1}$ and $4.6 \mathrm{\mu g} \mathrm{g}^{-1}$, respectively, for the $10 \mathrm{mg} \mathrm{kg}^{-1}$ dose and $6.5 \mathrm{\mu g} \mathrm{ml}^{-1}$ and $7.0 \mu \mathrm{g} \mathrm{g}^{-1}$, respectively, for the $20 \mathrm{mg} \mathrm{kg}^{-1}$ dose in cod, $24 \mathrm{~h}$ following the last application (Samuelsen \& Bergh 2004). These values therefore show that, following recommended medication with florfenicol (10 $\mathrm{mg} \mathrm{kg}^{-1}$ daily for 10 consecutive days), the mean concentrations in plasma will exceed the MIC value of $0.5 \mu \mathrm{g} \mathrm{ml}^{-1}$ by a good margin for the entire medication period and have the potential of providing a therapeutic effect (Samuelsen et al. 2003b). In comparison, a single dose of $10 \mathrm{mg} \mathrm{kg}^{-1}$ florfenicol to tilapia (Oreochromis niloticus $\times$ O. aureus) gave $C_{\max }$ concentrations of $4.46 \mu \mathrm{g} \mathrm{ml}^{-1}$ in plasma, $6.88 \mu \mathrm{g} \mathrm{g}^{-1}$

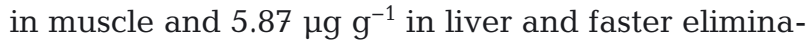
tion with $t_{1 / 2} \beta$ values of $10 \mathrm{~h}$ in plasma, $11 \mathrm{~h}$ in muscle and $14 \mathrm{~h}$ in liver (Feng \& Jia 2009), which is considerably lower than the values found in cod. However, according to Bowser et al. (2009) and Kosoff et al.
(2009), a $10 \mathrm{~d}$ administration of 10 and $15 \mathrm{mg} \mathrm{kg}^{-1} \mathrm{~d}^{-1}$ resulted in plasma and tissue concentrations in tilapia similar to or higher than those found in cod by Samuelsen \& Bergh (2004). Furthermore, a medication regime of $15 \mathrm{mg} \mathrm{kg}^{-1}$ daily for 10 consecutive days showed high efficacy in the treatment of a Francisella asiatica infection in tilapia if the drug was administered during the early stages of infection (1 to $3 \mathrm{~d}$ post challenge) (Soto et al. 2010). The MIC value for the bacterial isolate was $2.0 \mathrm{\mu g} \mathrm{ml}^{-1}$.

The MIC values for the combination of trimethoprim and sulphadiazin (Tribrissen) were from 64 to $128 \mu \mathrm{g} \mathrm{ml}{ }^{-1}$. No pharmacokinetic data following administration of this combination were available in cod, but a single oral administration of the comparable compounds ormethoprim $\left(5 \mathrm{mg} \mathrm{kg}^{-1}\right)$ and sulphadimethoxine (25 mg kg $\mathrm{kg}^{-1}$ ) in combination (Romet ${ }^{\circledR} 30$ ) showed plasma $C_{\max }$ values of $22.1 \mu \mathrm{g}$ $\mathrm{ml}^{-1}$ (sulphadimethoxine) and $1.6 \mathrm{\mu g} \mathrm{m}^{-1}$ (ormethoprim) after 72 and $9 \mathrm{~h}$, respectively. Corresponding values for muscle were $11.1 \mu \mathrm{g} \mathrm{g}^{-1}$ at $72 \mathrm{~h}$ and 2.0 $\mu \mathrm{g} \mathrm{g}^{-1}$ at $9 \mathrm{~h}$, respectively, and for liver $9.7 \mu \mathrm{g} \mathrm{g}^{-1}$ at $48 \mathrm{~h}$ and $14.7 \mu \mathrm{g} \mathrm{g}^{-1}$ at $6 \mathrm{~h}$, respectively (Samuelsen 2006b). Since a comparison of the pharmacokinetic properties of Tribrissen and Romet ${ }^{\circledR} 30$ revealed only minor differences in Atlantic salmon (Samuelsen et al. 1995, Horsberg et al. 1997), it is likely that this is valid also for cod. Our result therefore indicates that the concentrations of both drugs in plasma and tissues do not exceed the MIC values, and it is therefore unlikely that Tribrissen will have a therapeutic effect on cod.

The MIC value for oxytetracycline for all the Francisella noatunensis subsp. noatunensis strains tested in this investigation was found to be $64 \mathrm{\mu g} \mathrm{ml}^{-1}$. The pharmacokinetic profile for this drug has been studied in a number of marine fish species but not in cod (Elema et al. 1996, Rigos et al. 2003, 2004a,b, Wang et al. 2004). The plasma $C_{\max }$ for oxytetracycline varies considerably in marine fish, and the absorption of oxytetracycline from the intestine is, due to complexation with di- and tri-valent cations, normally rather low. The highest plasma concentration measured in marine fish species was in black seabream Sparus macrocephalus with $8.48 \mathrm{\mu g} \mathrm{ml}^{-1}$ (Wang et al. 2004) following administration of $100 \mathrm{mg} \mathrm{kg}^{-1}$ daily for $5 \mathrm{~d}$. If one can assume that the pharmacokinetic profile of oxytetracycline in cod is similar to the profiles in other marine fish species, the plasma concentrations will most certainly not reach a concentration high enough to exceed the MIC value of $64 \mu \mathrm{g} \mathrm{ml}^{-1}$. It is therefore unlikely that oxytetracycline will have a therapeutic effect in the treatment of a francisellosis 
infection in cod. In comparison, Chern \& Chao (1994) considered 10 to $14 \mathrm{~d}$ treatment with 30 to $50 \mathrm{mg} \mathrm{kg}^{-1}$ oxytetracycline as a most-likely effective treatment of infection with rickettsia-like organisms in tilapia. The MIC value for tetracycline was determined to be $1 \mu \mathrm{g} \mathrm{ml}^{-1}$ (Chern \& Chao 1994). Furthermore, Mauel et al. (2005) and Ostland et al. (2006) reported successful treatment of francisellosis in tilapia and striped bass Morone chrysops $\times$ M. saxatilis, respectively, using tetracycline. The dosage used by Ostland et al. (2006) was approximately $250 \mathrm{mg} \mathrm{kg}^{-1}$ daily for $10 \mathrm{~d}$.

A rather intensive and extended treatment of juvenile Chinook salmon Oncorhynchus tshawytscha with erythromycin $\left(100 \mathrm{mg} \mathrm{kg}^{-1}\right)$ daily for $3 \times 28 \mathrm{~d}$ during the period of February to June led to a maximum tissue concentration of $10.4 \mathrm{\mu g} \mathrm{g}^{-1}$ (Fairgrieve et al. 2005). No pharmacokinetic data for erythromycin exist for cod, but, with a MIC value of $16 \mu \mathrm{g} \mathrm{ml}^{-1}$ against all strains of Francisella noatunensis subsp. noatunensis tested, this drug will most probably not obtain concentrations high enough in cod to have a therapeutic effect.

Except for florfenicol, flumequine, oxolinic acid and rifampin, the antibacterial susceptibilities of the Francisella noantuensis subsp. noatunensis isolates tested in the present study were low (Table 1). In comparison, a number of studies testing the susceptibility of these antibacterial agents to strains of the bacterium Francisella tularensis, in general, showed higher susceptibility (Maurin et al. 2000, Johansson et al. 2002, Tomaso et al. 2005, Urich \& Petersen 2008). The MIC values varied from 0.125 to $4 \mu \mathrm{g} \mathrm{ml}^{-1}$ for tetracycline, 0.032 to $8 \mu \mathrm{g} \mathrm{ml}^{-1}$ for streptomycin sulphate, 0.12 to $4 \mathrm{\mu g} \mathrm{ml}^{-1}$ for erythromycin, 0.015 to $2 \mu \mathrm{g} \mathrm{ml}^{-1}$ for rifampin and 0.004 to $0.25 \mu \mathrm{g} \mathrm{ml}^{-1}$ for ciprofloxacin. One study, however, showed lower susceptibility, with MIC values of 4 to $64 \mathrm{\mu g} \mathrm{ml}^{-1}$ for tetracycline, 4 to $32 \mathrm{\mu g} \mathrm{ml}^{-1}$ for streptomycin sulphate, and 4 to 16 and 0.06 to $0.25 \mu \mathrm{g} \mathrm{ml}^{-1}$, respectively, for the quinolones nalidixic acid and ciprofloxacin (García del Blanco et al. 2004).

In conclusion, florfenicol and the quinolones flumequine and oxolinic acid seem to be the best alternatives for treatment based on MIC values and available pharmacokinetic data.

\section{LITERATURE CITED}

Alderman DJ, Smith P (2001) Development of draft protocols of standard reference methods for antimicrobial agent susceptibility testing of bacteria associated with fish diseases. Aquaculture 196:211-243
Andrews JM (2001) Determination of minimum inhibitory concentrations. J Antimicrob Chemother 48:5-16

Birkbeck TH, Feist SW, Verner-Jeffreys DW (2011) Francisella infections in fish and shellfish. J Fish Dis 34:173-187

> Bohle H, Tapia E, Martìnez A, Rozas M, Figueroa A, Bustos P (2009) Francisella philomiragia, bacteria asociada con altas mortalidades en salmons del Atlantico (Salmo salar) cultivados en balsas-jaulas en el lago Llanquihue. Arch Med Vet 41:237-244 (in Spanish)

$>$ Bowser PR, Kosoff RE, Chen CY, Wooster GA and others (2009) Florfenicol residues in Nile tilapia after 10-d dosing in feed: effect of fish size. J Aquat Anim Health 21: 14-17

> Chern RS, Chao CB (1994) Outbreaks of a disease caused by rickettsia-like organisms in cultured tilapias in Taiwan. Fish Pathol 29:61-71

> Colquhoun DJ, Duodu S (2011) Francisella infections in farmed and wild aquatic organisms. Vet Res 42:47-62

Elema MO, Hoff KA, Kristensen HG (1996) Bioavailability of oxytetracycline from medicated feed administered to Atlantic salmon (Salmo salar L.) in seawater. Aquaculture 143:7-14

> Fairgrieve WT, Masada CL, McAuley WC, Peterson ME, Myers MS, Strom MS (2005) Accumulation and clearance of orally administered erythromycin and its derivative, azithromycin, in juvenile fall Chinook salmon Oncorhynchus tshawytscha. Dis Aquat Org 64:99-106

> Feng JB, Jia XP (2009) Single dose pharmacokinetic study of florfenicol in tilapia (Oreochromis niloticus $\times$ O. aureus) held in freshwater at $22^{\circ} \mathrm{C}$. Aquaculture 289:129-133

García del Blanco N, Gutiérrez-Martín CB, De la PuenteRedondo VA, Rodrígues Ferri EF (2004) In vitro susceptibility of field isolates of Francisella tularensis subsp. holarctica recovered in Spain to several antimicrobial agents. Res Vet Sci 76:195-198

Hansen MK, Horsberg TE (2000) Single-dose pharmacokinetics of flumequine in cod (Gadus morhua) and goldsinny wrasse (Ctenolabrus rupestris). J Vet Pharmacol Ther 23:163-168

Hjeltnes B (2009) Farmed fish health report 2008. National Veterinary Institute, Oslo

Horsberg TE, Martinsen B, Sandersen K, Zernichow L (1997) Potentiated sulphonamides: in vitro inhibitory effects and pharmacokinetic properties in Atlantic salmon in seawater. J Aquat Anim Health 9:203-210

Johansson A, Urich SK, Chu MC, Sjöstedt A, Tärnvik A (2002) In vitro susceptibility to quinolones of Francisella tularensis subspecies tularensis. Scand J Infect Dis 34: 327-330

> Kosoff RE, Chen CY, Wooster GA, Getchell RG and others (2009) Florfenicol residues in three species of fish after 10-d dosing in feed. J Aquat Anim Health 21:8-13

> Lewin CS, Hastings TS (1990) In vitro activities of oxolinic acid, ciprofloxacin and norfloxacin against Aeromonas salmonicida. J Fish Dis 13:377-384

> Mauel MJ, Miller DL, Styer E, Pouder DB, Yanong RP, Goodwin AE, Schwedler TE (2005) Occurrence of piscirickettsiosis-like syndrome in tilapia in the continental United States. J Vet Diagn Invest 17:601-605

> Maurin M, Mersali NF, Raoult D (2000) Bactericidal activities of antibiotics against intracellular Francisella tularensis. Antimicrob Agents Chemother 44:3428-3431

Mikalsen J (2008) Diagnosis and characterisation of intracellular Gram-negative pathogens of marine and salmonid fish. Thesis, Norwegian School of Veterinary Science, Oslo 
Nylund A, Ottem KF, Watanabe K, Karlsbakk E, Krossøy B (2006) Francisella sp. (family Francisellaceae) causing mortality in Norwegian cod (Gadus morhua) farming. Arch Microbiol 185:383-392

Olsen AB, Mikalsen J, Rode M, Alfjorden A and others (2006) A novel systemic granulomatous inflammatory disease in farmed Atlantic cod, associated with a bacterium belonging to the genus Francisella. J Fish Dis 29: 307-311

> Ostland VE, Stannard JA, Creek JJ, Hedrick RP, Ferguson HW, Calberg JM, Westerman ME (2006) Aquatic Francisella-like bacterium associated with mortality of intensively cultured hybrid striped bass Morone chrysops $\times$ M. saxatilis. Dis Aquat Org 72:135-145

> Ottem KF, Nylund A, Karlsbakk E, Friis-Møller A, Krossøy B, Knappskog D (2007) New species in the genus Francisella (Gammaproteobacteria; Francisellaceae); Francisella piscida sp. nov. isolated from cod (Gadus morhua). Arch Microbiol 188:547-550

$>$ Ottem KF, Nylund A, Isaksen TE, Karlsbakk E, Bergh Ø (2008) Occurrence of Francisella piscicida in farmed and wild Atlantic cod, Gadus morhua L., in Norway. J Fish Dis 31:525-534

Rigos G, Nengas I, Tyrpenou AE, Alexis M, Troisi GM (2003) Pharmacokinetics and bioavailability of oxytetracycline in gilthead sea bream (Sparus aurata) after a single dose. Aquaculture 221:75-83

Rigos G, Tyrpenou AE, Nengas I, Alexis M, Athanassopoulou F, Troisi GM (2004a) Poor bioavailability of oxytetracycline in sharpsnout sea bream Diplodus puntazzo. Aquaculture 235:489-497

Rigos G, Nengas I, Alexis M, Athanassopoulou F (2004b) Bioavailability of oxytetracycline in sea bass, Dicentrarchus labrax L. J Fish Dis 27:119-122

Samuelsen OB (2006a) Multiple dose pharmacokinetic study of oxolinic acid in cod. Aquacult Int 14:443-450

Samuelsen OB (2006b) Absorption, tissue distribution, metabolism and excretion of ormetoprim and sulphadimethoxine in cod after oral administration of Romet ${ }^{30}$. J Appl Ichthyology 22:68-71

Samuelsen OB, Bergh Ø (2004) Efficacy of orally administered florfenicol and oxolinic acid for the treatment of

Editorial responsibility: David Bruno,

Aberdeen, UK vibriosis in cod (Gadus morhua). Aquaculture 235:27-35

Samuelsen OB, Ervik A, Wennevik V (1995) Absorption, tissue distribution, metabolism and excretion of ormetoprim and sulphadimethoxine in Atlantic salmon (Salmo salar) after intravenous and oral administration of Romet. Xenobiotica 25:1169-1180

> Samuelsen OB, Bergh Ø, Ervik A (2003a) A single-dose pharmacokinetic study of oxolinic acid and vetoquinol, an oxolinic acid ester, in cod, Gadus morhua L., held in sea water at $8^{\circ} \mathrm{C}$ and in vitro antibacterial activity of oxolinic acid against Vibrio anguillarum strains isolated from diseased cod. J Fish Dis 26:339-347

Samuelsen OB, Bergh Ø, Ervik A (2003b) Pharmacokinetics of florfenicol in cod Gadus morhua and in vitro antibacterial activity against Vibrio anguillarum. Dis Aquat Org 56:127-133

> Shojaee AliAbadi F, Lees P (2000) Antibiotic treatment for animals: effect on bacterial population and dosage regimen optimisation. Int J Antimicrob Agents 14:307-313

Soto E, Endris RG, Hawke JP (2010) In vitro and in vivo efficacy of florfenicol for treatment of Francisella asiatica infection in Tilapia. Antimicrob Agents Chemother 54: 4664-4670

Soto E, Griffin M, Wiles J, Hawke JP (2012) Genetic analysis and antimicrobial susceptibility of Francisella noatunensis subsp. orientalis (syn. F. asiatica) isolated from fish. Vet Microbiol 154:107-412

> Tomaso H, Al Dahouk S, Hofer E, Splettstoesser WD, Treu TM, Dierich MP, Neubauer H (2005) Antimicrobial susceptibilities of Austrian Francisella tularensis holarctica biovar II strains. Int J Antimicrob Agents 26:279-284

Urich SK, Petersen JM (2008) In vitro susceptibility of isolates of Francisella tularensis types A and B from North America. Antimicrob Agents Chemother 52:2276-2278

$>$ Vik-Mo FT, Bergh Ø, Samuelsen OB (2005) Efficacy of orally administrated flumequine in the treatment of vibriosis caused by Listonella anguillarum in Atlantic cod Gadus morhua. Dis Aquat Org 67:87-92

- Wang Q, Liu Q, Li J (2004) Tissue distribution of oxytetracycline in perch (Lateolabras janopicus) and black seabream (Sparus macrocephalus) following oral administration. Aquaculture 237:31-40

Submitted: July 14, 2011; Accepted: November 29, 2011 Proofs received from author(s): February 9, 2012 